\title{
Skin Burn after Sacroiliac Denervation: An Unusual but Significant Complication
}

\author{
Charles Amaral de Oliveira, MD¹, André Mansano, MD, PhD¹, Fabricio Dias Assis, MD¹, and \\ Andrea Trescot, MD²
}

Radiofrequency (RF) lesioning, developed in 1965 , has been very useful in pain medicine, providing long-term relief for many chronic pain problems by denervating the regions involved in the generation of pain. The technique involves the use of a probe placed into the targeted tissue to be ablated. An electrical current is then passed from the machine to the tip of the probe, ionically heating up the tissues, which destroys the nerve tissue. The circuit is completed when the electrons are collected by a distal dispersing electrode that carries the current back to the generator. The potential sites for RF lesioning are expanding, and this has led to an expansion of the use of RF in a variety of medical fields, including cardiology, gastroenterology, otolaryngology, neurosurgery, and pain medicine. The size of the probes is increasing as well, as is the length of time used in lesioning, which increases the power and therefore the electrical field generated by the ablating system. By the nature of the electrical field created, the RF technique creates a risk of superficial (and potentially deep) burns at the dispersive electrode. This small but significant risk of burns has been reported after cardiac and gastrointestinal ablation, but has not been emphasized to practicing pain physicians. We present here the case report of a significant burn at the dispersive electrode site after a denervation procedure of the sacroiliac joint. We describe the mechanism of injury and propose potential methods of prevention.

Key words: Radiofrequency lesioning, sacroiliac denervation, complications, sacroiliac joint treatment
Sacroiliac joints (SIJ) are an important source of low back (1) and lower limb pain (2). Clinical assessment and SIJ infiltration are the cornerstone of diagnosis. Patients resistant to conservative management may benefit from sacroiliac radiofrequency (RF) denervation (3-11), a relatively safe procedure done under light sedation and local anesthesia, with low reported rates of complication (11-13).

We report a case of a middle-aged patient who underwent sacroiliac RF denervation and developed a postprocedure thigh skin burn.

From : ${ }^{1}$ Singular Pain Center, São Paulo, Brazil; ${ }^{2}$ Pain and Headache Center, Eagle River, AK, USA

Author for correspondence: Andrea Trescot, MD

Address: Pain and Headache Center, 12836 Old Glenn Hwy, Eagle River, AK 99577

E-mail: DrTrescot@gmail.com

\section{CASE REPORT}

A 52-year-old man presented with bilateral lower lumbar and gluteal pain, resistant to conservative treatment. The physical examination was consistent with sacroiliac joints involvement, as evidenced by bilateral positive distraction and Patrick tests. The lumbar spine magnetic resonance showed no abnormalities except for disc degeneration at L5-S1. The patient underwent bilateral sacroiliac joint injections with $3 \mathrm{~mL}$ of lidocaine $2 \%$ plus methylprednisolone $40 \mathrm{mg}$ at each site; he reported a decrease in his visual analog scale from 7 to 2 . The pain returned after a few days, and he was scheduled for a bilateral sacroiliac denervation as the next treatment approach.

After an intravenous line was established, the patient was monitored while prone with a pillow beneath his abdomen to reduce the lumbar lordotic curvature. A disposable dispersive plate was applied to the 
posterior right thigh. The lumbar region and buttocks were prepared and draped in a sterile fashion. An anteroposterior $\mathrm{C}$-arm projection was obtained, centered on the inferior border of the sacrum. The skin entry point was identified at the inferior border of the sacrum, one centimeter lateral to and below the $\mathrm{S} 4$ foramen. The patient was given light sedation with midazolam $2 \mathrm{mg}$, fentanyl $50 \mu \mathrm{g}$, and propofol 4 cc. The aimed track of the Simplicity IIITM electrode (St. Jude Medical, St. Paul, Minnesota) was anesthetized with $1 \%$ lidocaine via a 25-gauge 3-1/2 inch Quincke needle. The Simplicity III electrode was correctly inserted along the posterior surface of the sacrum, lateral to the sacral foramina and medial to the sacroiliac joint (Fig. 1). We then lesioned the site by using the Simplicity III ${ }^{\mathrm{TM}}$ pre-programmed steps using a Neurotherm ${ }^{\mathrm{TM}}$ generator model NT 1100 (St. Jude Medical, St. Paul, Minnesota). At the end of the procedure, the patient underwent an additional L5 primary dorsal ramus RF lesioning. The procedure was performed on both sides and was uneventful. After the procedure, in the postanesthesia care unit,
2 burn lesions were noted at the posterior right thigh, initially with blister formations and quickly turning to second degree burn lesions, one measuring $1.5 \mathrm{~cm}$ $X 5 \mathrm{~cm}$ and another measuring $0.8 \mathrm{~cm} \times 1 \mathrm{~cm}$ (Fig. 2). The patient was referred to a dermatologist and appropriately treated.

\section{DISCUSSION}

The use of RF lesioning in the treatment of pain was initially described in 1965 by Mullan (14) using a direct current. Subsequently, the technique was modified by Rosomoff et al (15) to use RF current, hoping that RF would produce a more predictable lesion. A few years later, Sweet and Wepsic (16) described their technique for RF lesioning of the Gasserian ganglion to treat intractable trigeminal neuralgia. The first commercial generators, developed by Aranow (17) and Cosman (18) were released in the 1950s and used higher frequency, in the range of $300-500 \mathrm{KHz}$, to produce more reliable lesions. Since high frequencies in this range were also used in radio transmitters, the term "radiofrequency lesioning" was coined.

The generator creates an electrical current at the active electrode (e.g., the tip of the needle or, as in this case, the Simplicity III ${ }^{\mathrm{TM}}$ electrodes), which then flows to the dispersive plate (Fig. 3).

This complication is more frequently reported following RF ablation of solid tumors, occurring in $0.1 \%$ to $3 \%$ of cases (19-23) as well as after arrhythmia ablations, most likely because of the time length of the cases and the high energy used to accomplish these procedures. Burns are rare with RF lesioning for pain, and are usually due to electrical faults, insulation breaks, or machine malfunctioning (24). There have been 8 reported cases of superficial burns at the needle puncture site (but not the dispersive plate) (25). We found only one case report of thermal lesion by a dispersive plate, caused by an intradiscal electrothermal therapy (IDET) RF ablation (25) and so the patient is seldom warned about the risk.
Fig. 1. Fluoroscopic image of Simplicity III ${ }^{\mathrm{TM}}$ probe in place over the sacroiliac joint. 
The electrical burns can be caused by high RF current density from the generator or by direct current from the malfunctioning device (26). It usually occurs because of an alternate current pathway during monopolar mode or because of moisture beneath the negative electrode (27), but any fluid (like blood or saline) may create alternate current pathways and cause thermal lesions (28). Maladaptive dispersive plates may occur due to the drying of the electrode gel, incorrect position on a hairy area or on a sharply angled surface like a bone eminence.

In this case report, the dispersive plate apparently had insufficient contact with the hairy skin surface and the current density was dramatically increased in the contact area. Curiously, the patient was under only light sedation, was able to reply to the stimulus, and didn't complain about thigh pain during the RF procedure.

\section{CONCLUSION}

This article was written to warn pain practitioners regarding the potential danger from dispersive electrode burns. As the RF probes for pain treatment get larger and the heating times longer (such as with cooled RF and sacroiliac denervation procedures), the risk of unintended thermal lesions increase. Meticulous care must be taken when placing the dispersing plate, by assuring that the gel is fresh, that the plate is evenly

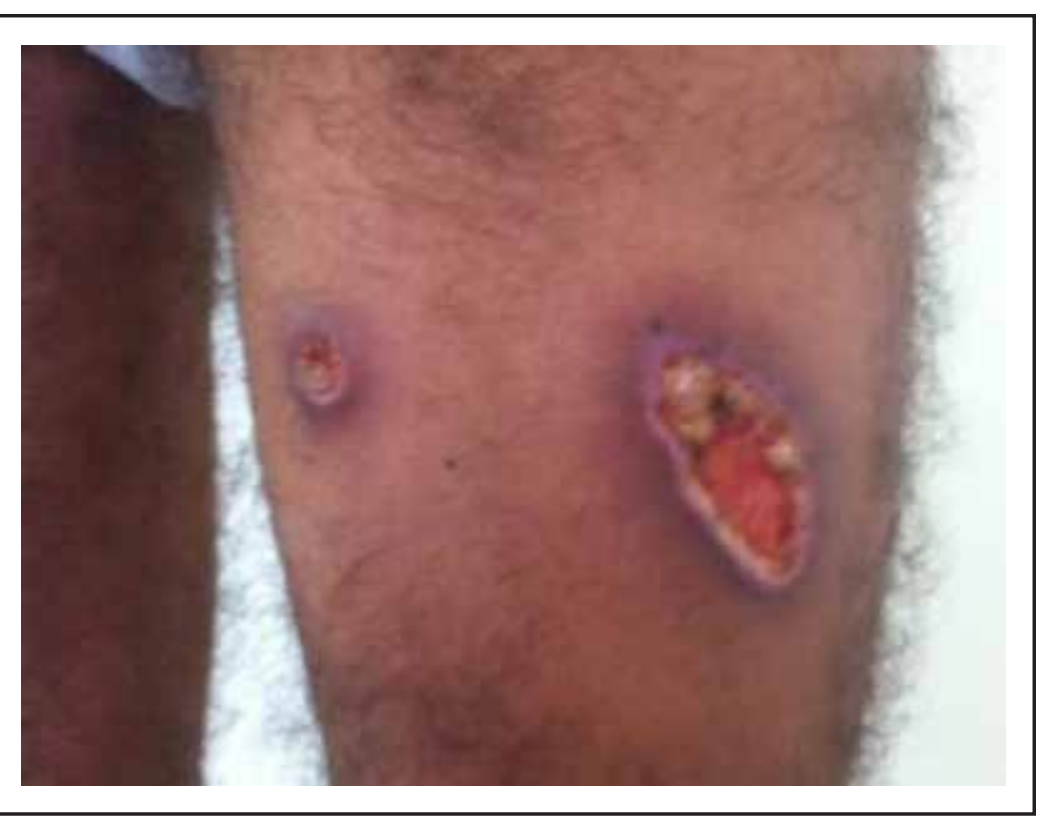

Fig. 2. Full thickness burns at the site of the dispersing plate.

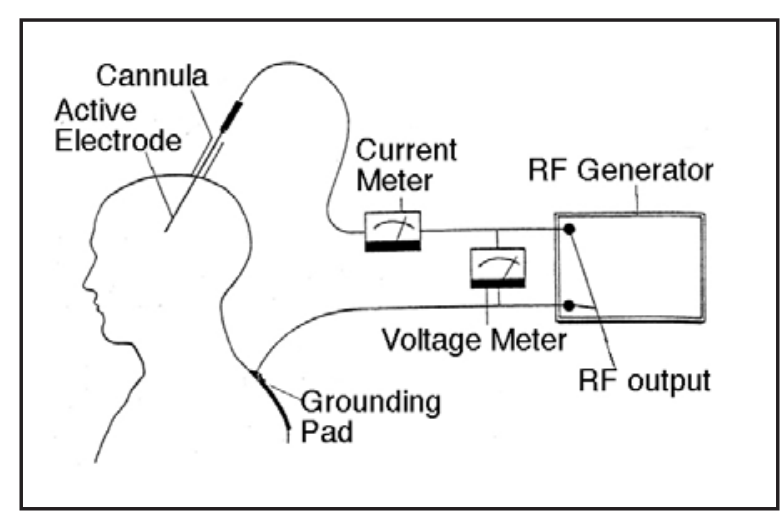

Fig. 3. Radiofrequency circuit.

[Image from Trescot AM, Hansen HC. Radiofrequency neurolysis. In: Manchikanti L and Singh V (eds). Interventional Techniques in Chronic Non-spinal Pain. American Society of Interventional Pain Physicians Publishing, Paducah, KY, 2009 (with permission)]. adhering to the tissues, and that an appropriate site has been selected.

For these longer, larger procedures, perhaps the consents should include the risk of burns, which will hopefully be decreased by preprocedure care.

\section{Conflict of Interest}

We confirm that there has been no conflict of interest, and no corporate sponsorship or funding. 


\section{REFERENCES}

1. Forst SL, Wheeler MT, Fortin JD, Vilensky JA. The sacroiliac joint: Anatomy, physiology and clinical significance. Pain Physician 2006; 9:61-67.

2. Slipman CW, Jackson HB, Lipetz JS, Chan KT, Lenrow D, Vresilovic EJ. Sacroiliac joint pain referral zones. Arch Phys Med Rehabil 2000; 81:334-338.

3. Vallejo R, Benyamin RM, Kramer J, Stanton G, Joseph NJ. Pulsed radiofrequency denervation for the treatment of sacroiliac joint syndrome. Pain Med 2006; 7:429-434.

4. Kapural L, Stojanovic M, Sessler DI, Bensitel T, Zovkic P. Cooled radiofrequency (RF) of L5 dorsal ramus for RF denervation of the sacroiliac joint: Technical report. Pain Med 2010; 11:53-57.

5. Kapural L, Nageeb F, Kapural M, Cata JP, Narouze S, Mekhail $\mathrm{N}$. Cooled radiofrequency system for the treatment of chronic pain from sacroiliitis: The first case-series. Pain Pract 2008; 8:348-354.

6. Rupert MP, Lee M, Manchikanti L, Datta S, Cohen SP. Evaluation of sacroiliac joint interventions: A systematic appraisal of the literature. Pain Physician 2009; 12:399-418.

7. Burnham RS, Yasui Y. An alternate method of radiofrequency neurotomy of the sacroiliac joint: A pilot study of the effect on pain, function, and satisfaction. Reg Anesth Pain Med 2007; 32:12-19.

8. Gevargez A, Groenemeyer D, Schirp S, Braun M. CT-guided percutaneous radiofrequency denervation of the sacroiliac joint. Eur Radiol 2002; 12:1360-1365

9. Ferrante FM, King LF, Roche EA, Kim PS, Aranda M, Delaney LR, Mardini IA, Mannes AJ.. Radiofrequency sacroiliac joint denervation for sacroiliac syndrome. Reg Anesth Pain Med 2001; 26:137-142.

10. Cohen SP, Foster A. Pulsed radiofrequency as a treatment for groin pain and orchialgia. Urology 2003; 61:645

11. Cohen SP, Hurley RW, Buckenmaier CC, 3rd, Kurihara C, Morlando B, Dragovich A. Randomized placebo-controlled study evaluating lateral branch radiofrequency denervation for sacroiliac joint pain. Anesthesiology 2008; 109:279-288.

12. Cohen SP, Strassels SA, Kurihara C, Crooks MT, Erdek MA, Forsythe A, Marcuson M. Outcome predictors for sacroiliac joint (lateral branch) radiofrequency denervation. Reg Anesth Pain Med 2009; 34:206-214.

13. Dreyfuss P, Snyder BD, Park K, Willard F, Carreiro J, Bogduk $\mathrm{N}$. The ability of single site, single depth sacral lateral branch blocks to anesthetize the sacroiliac joint complex. Pain Med 2008; 9:844-850

14. Mullan S, Hekmatpanah J, Dobben G, Beckman F. Percutane- ous, intramedullary cordotomy utilizing the unipolar anodal electrolytic lesion. J Neurosurg 1965; 22:548-553.

15. Rosomoff HL, Sheptak P, Carroll F. Modern pain relief: Percutaneous chordotomy. JAMA 1966; 196:482-486

16. Sweet WH, Wepsic JG. Controlled thermocoagulation of trigeminal ganglion and rootlets for differential destruction of pain fibers. 1. Trigeminal neuralgia. J Neurosurg 1974; 40:143-156.

17. Aranow $\mathrm{S}$. The use of radiofrequency power in making lesions in the brain. J Neurosurg 1960; 17:431-438.

18. Cosman BJ, Cosman ER. Guide to Radio Frequency Lesion Generation in Neurosurgery. Radionics, Burlington, MA, 1974.

19. Rhim H, Yoon KH, Lee JM, Cho Y, Cho JS, Kim SH, Lee WJ Lim HK, Nam GJ, Han SS, Kim YH, Park CM, Kim PN, Byun JY. Major complications after radio-frequency thermal ablation of hepatic tumors: Spectrum of imaging findings. Radiographics 2003; 23:123-134; discussion 34-36.

20. Steinke K, Gananadha S, King J, Zhao J, Morris DL. Dispersive pad site burns with modern radiofrequency ablation equipment. Surg Laparosc Endosc Percutan Tech 2003; 13:366-371.

21. Mulier S, Mulier P, Ni Y, Miao Y, Dupas B, Marchal G, De Wever I, Michel L. Complications of radiofrequency coagulation of liver tumours. Br J Surg 2002; 89:1206-1222.

22. Baek JH, Lee JH, Sung JY, Bae JI, Kim KT, Sim J, Baek SM Kim YS, Shin JH, Park JS, Kim DW, Kim JH, Kim EK, Jung SL, Na DG; Korean Society of Thyroid Radiology. Complications encountered in the treatment of benign thyroid nodules with USguided radiofrequency ablation: A multicenter study. Radiology 2011; 262:335-342

23. Huffman SD, Huffman NP, Lewandowski RJ, Brown DB. Radiofrequency ablation complicated by skin burn. Semin Intervent Radiol 2012; 28:179-182.

24. Colonno DV, Harrast MA, Herring SA. Overview of spinal interventions. Clin Sports Med 2012; 31:409-422.

25. Bogduk N, Dreyfuss P, Baker R, Yin W, Landers M, Hammer M, Aprill C. Complications of spinal diagnostic and treatment procedures. Pain Medicine 2008; 9:511-534.

26. Russell MJ, Gaetz M. Intraoperative electrode burns. J Clin Monit Comput 2004; 18:25-32.

27. Demir E, O'Dey DM, Pallua N. Accidental burns during surgery. J Burn Care Res 2006; 27:895-900.

28. Pearce JA, Geddes LA, Van Vleet JF, Foster K, Allen J. Skin burns from electrosurgical current. Med Instrum 1983; 17:225231. 